\title{
Preliminary Reflexion on Road Basic Components for Road Infrastructure Preservation Works - a Review
}

\author{
Pemikiran Awal tentang Komponen Dasar Jalan bagi Pekerjaan \\ Preservasi Infrastruktur Jalan - sebuah Kajian
}

\author{
Ria Asih Aryani Soemitro ${ }^{1, a)}$ \& Hitapriya Suprayitno ${ }^{1, b)}$ \\ ${ }^{1)}$ Departement of Civil Engineeringl, Institut Teknologi Sepuluh Nopember (ITS), Surabaya.
}

Correspondance : ria@ce.its.ac.id \& suprayitno.hita@gmail.com

\begin{abstract}
Road Maintenance Program has been changed as Road Preservation Program. This is due to the years of permanent distress on flexible pavement even if yearly maintenance works have been always done. This concept changing give various several important questions. One of these is how the road components should be classified. Finally, it can be noted that classification must be built based on road space and road physical components and the importance level in carrying out the road function. Brief, first the basic road physical components for flowing the traffic, second the road physical components for facilitating basic public facilities that must be placed along the road network. The first components basically consist of pavement, drainage, sign \& marking, guard-rail, shoulder. While the second components consist of greenery, and facility, such as for electrical line, telephone line, potable water pipe, gas pipe, etc.
\end{abstract}

Keywords : road infrastructure asset management, road preservation, road components.

\section{INTRODUCTION}

Asset Management has become a mantra in Indonesia nowadays. It is a common practice in Indonesia for public physical assets. Public Infrastructure as assets are very capital for the region's life, among which road infrastructures are the preliminary requirements for public infrastructures (ISO 55000; PerMen PUPR 34/16; PP 34/06; Suprayitno \& Soemitro, 2018; UU 38/04; UU 1/04).

The idea of implementing Asset Management in Indonesia for Public Assets was started in 2004. This is due to the issuance of Law Number 1 Year 2004 on State Treasury. After this Law Issuance a lot of preparation works for Public Asset Management can be executed. Ten years after the government issued the Government Regulation Number 27 Year 2014 on Management of State or Region Asset. Then, the real implementation of Asset Management for Public Assets can be started (UU 1/04; PP 27/14; PP 28/20).

In Japan, the term of Infrastructure Asset Management is stressed more in the managing of the Built Infrastructures. It means that this deals with the Operation and the Maintenance of the Infrastructure. It deals with the utilisation of the infrastructures, in which the infrastructure is built for (Suprayitno, 2021; Suprayitno \& Soemitro, 2021).

Later on, concerning the road infrastructures in Indonesia, the Maintenance Program has been changed into the Preservation Program. The main objective slightly changed, those the works involved has been slightly changed (Sinaga, 2011).

A lot of questions arose from this changing (Kiranasari et al, 2020). One of the most important one is which main road components is subject to the road preservation work. 


\section{RESEARCH METHOD}

This paper has been written based on several discussion with whom having knowledge on this matter, certain review on related references and a series of reflexions. All of the study was started with a formulation of principal question, follows by formulating the item to be discussed in the paper.

\section{ROAD PRESERVATION WORK BASIC COMPONENTS}

\section{Infrastructure Asset Management}

Infrastructure Asset Management is defined as the work, knowledge and science to manage the infrastructure along its whole lifecycle, in order that the infrastructure is always capable to function well, according to its planned function, which must be in accordance to the need of the served regions needs. It must be managed in efficient, effective, and economic way. It must be in accordance to the principle of sustainability. All pertinent risks must be well considered (ISO 55000; PP 28/20; Suprayitno \& Soemitro, 2018).

In general, the whole management works can be grouped into four distinct different groups of works: the administration \& evaluation work, the operation \& maintenance work, the procurement work, and the institutional work (Suprayitno \& Soemitro, 2021).

In Japan, the Infrastructure Asset Management cover more the Operation and Maintenance $(\mathrm{O} \& \mathrm{M})$ of the already constructed Infrastructures (Suprayitno \& Soemitro, 2021).

\section{Road Infrastructure Network Function}

In this research, the Road Infrastructure Function must be defined first, since the primary objective of the road asset management is to ensure that the infrastructure is always capable to execute its function well (Suprayitno \& Soemitro, 2019).

Basically, the primary functions of the national road are to connect different nodes of the served region and to flow the traffic in the served region. The secondary functions here is defined to help to create the green strip, to help to provide space for facility line, and to help to provide space for advertising etc (Suprayitno, 2014).

\section{Road Preservation}

In Directorate General of Highway, the Directorate of Road Maintenance is now called as the Directorate of Road Preservation. To ensure the pavement steady condition, the Road Maintenance Program has been changed into the Road Preservation Program (Sinaga, 2011).

Road Maintenance was defined as to maintain all of the important road components in order to be in good condition, to improve the deterioration to be in good condition. While Road Preservation is defined as works to ensure that the road always in good steady condition all of the time. Theoretically, it means that at any time of the day, there should be no any deterioration on the road (Sinaga, 2011).

\section{Principle Road Components}

The first thing to be understood is the principal road components. Since Road Preservation is to ensure that road conditions must be always in good condition, it means that all road components must be always in good condition. Road Components are classified into Road Space Components and Road Physical Components (PP 34/06).

Road Space Components is a division of the road space into traffic used space (rumaja: ruang manfaat jalan - Indonesian), right of way (rumija: ruang milik jalan - Indonesian), and road regulated space (ruwasja: ruang pengawasan jalan - Indonesian) (PP 34/06). Illustration of Road Space Components is presented in Figure 1 as follow. 


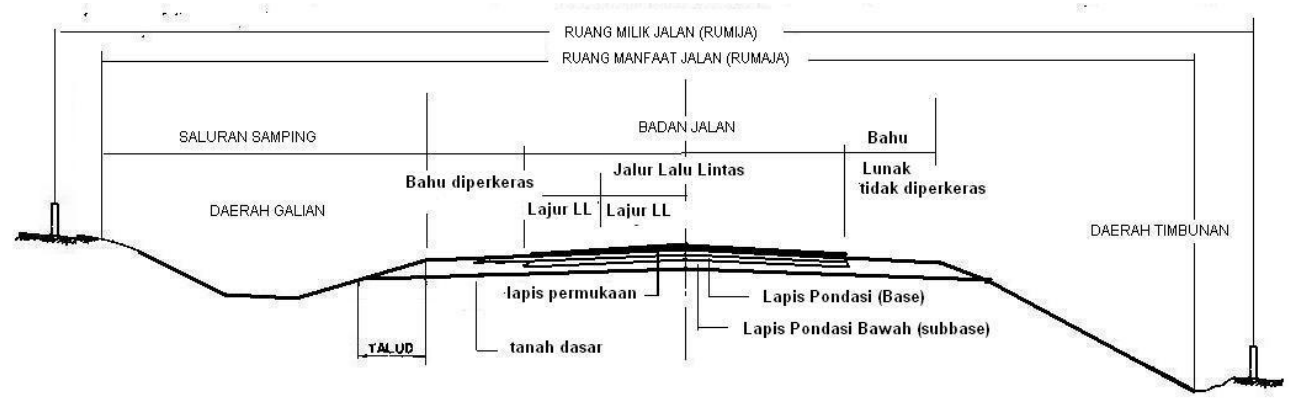

Figure 1. Typical Road Space Components

Road Physical Components can be divided as the pavement, the road marking \& sign, the traffic light, the drainage system, the street light, the sidewalk, the shoulder, the curb, the guard structure, the greenery, the other transport facility (such as parking facility, bus lane facility, bus stop facility, tramway facility, and others), the other facility structure (such as electricity line, potable water pipe, telecommunication line, gas pipe, etc) (Dewi et al, 2020, PP 34/06). The illustration of the Road Physical Components is presented in Figure 2 as follow.

\section{CROSS SECTION OF A ROAD}

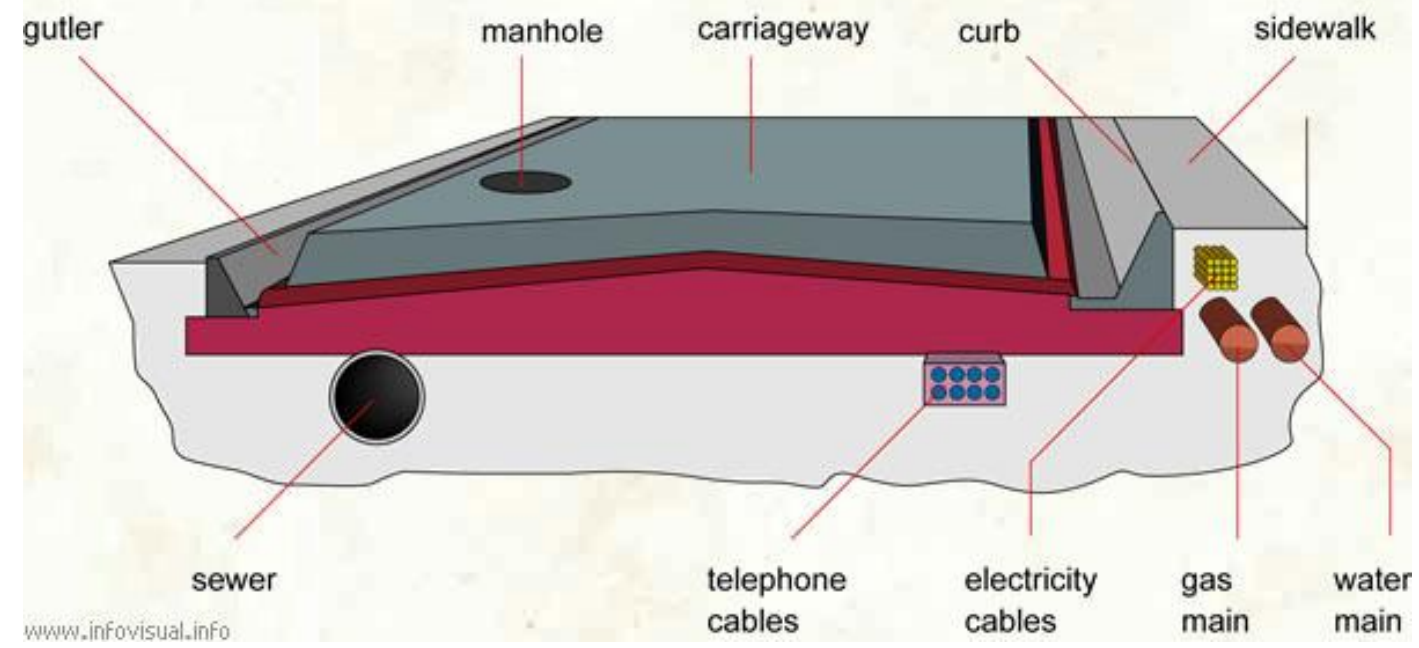

Figure 2. Illustration of Road Cross Section Components

\section{Principle Road Preservation Works}

Road Preservation consists of work, plan, knowledge and science to preserve the road condition to be always in good steady condition any time of the day. This involve several important thinking.

The first consideration is that the road consists of several road spaces and road physical components. The importance of each road components is different each one to the other for the good functionality of the road. The road function itself can be classified, in a simplified way, into the primary and the secondary functions (Suprayitno \& Soemitro, 2019). These must be considered.

The second is that the road maintenance works are normally to be contracted to the contractor. Therefore, the road preservation works must be contracted to the contractors also. There exist several questions on how the contracted work volume should be calculated, how the unit price must be calculated, how the work volume must be calculated, etc (Kiranasari et al, 2020). 
This sub-chapter try to systemize the importance of different road components in ensuring the functionality of the road function. The road functions are grouped into primary function and secondary function. The research discussing only the primary function, to flow the traffic. While secondary function is considered consists of to make greenery and to give facility for line public facility (electrical line, telecommunication line, potable water line, etc), and to give space or facility for advertising board (Dewi et al, 2020; Suprayitno, 2014).

The Importance Level of the Road Components has to be established differently for the primary function and for the secondary function. Therefore, the first thing to do is to develop a matrix consisting of the function, the road components and the importance level. Then, attributes have to be assigned to each function. These attributes are the quality components of the functions, based on which the importance levels are measured. The Importance Level table is presented in Table 1 as follows (Ridwan \& Putranto, 2020, Suprayitno \& Soemitro, 2019).

Table 1. Importance Level of Road Components in Preservation Works

\begin{tabular}{|c|c|c|c|c|}
\hline Function & & Attribut & Components & Importance \\
\hline \multirow{8}{*}{ Primary } & \multirow{8}{*}{ to flow the traffic } & \multirow{8}{*}{$\begin{array}{l}\text { safety, } \\
\text { comfortable, } \\
\text { fluid, } \\
\text { economical }\end{array}$} & pavement layers & 10 \\
\hline & & & drainage & 9 \\
\hline & & & shoulder & 8 \\
\hline & & & marking \& sign & 8 \\
\hline & & & traffic sign & 6 \\
\hline & & & sidewalk & 6 \\
\hline & & & road lighting & 6 \\
\hline & & & guard rail & 6 \\
\hline \multirow{3}{*}{ Secondary } & green & $\begin{array}{l}\text { green, shady } \\
\text { ambiance, } \\
\text { bird }\end{array}$ & $\begin{array}{l}\text { tree, shrubs, bush, } \\
\text { grassy }\end{array}$ & 8 \\
\hline & \multirow[b]{2}{*}{ facility } & $\begin{array}{l}\text { enough } \\
\text { space, } \\
\text { ducting } \\
\end{array}$ & $\begin{array}{l}\text { space for facility, } \\
\text { ducting }\end{array}$ & 8 \\
\hline & & $\begin{array}{l}\text { enough } \\
\text { space, } \\
\text { advertising } \\
\text { board } \\
\end{array}$ & space for advertisemen & 4 \\
\hline
\end{tabular}

\section{Principle Flexible Pavement Deterioration}

As mentioned before, the road components must be preserved absolutely to ensure a good functioning of the road is the pavement. It is such, since the main function of the road is to flow traffic on its served region. In Indonesia most pavements are flexible pavement. So now it is time to note different deterioration types of different flexible pavement components.

Flexible Pavement Components can be regarded as consist of the following main components: the pavement surface layer, the base \& sub-base layer, the subgrade layer, and the terrain soil layer (Hoffman, 2008). These Flexible Pavement components are illustrated in Figure 3. 


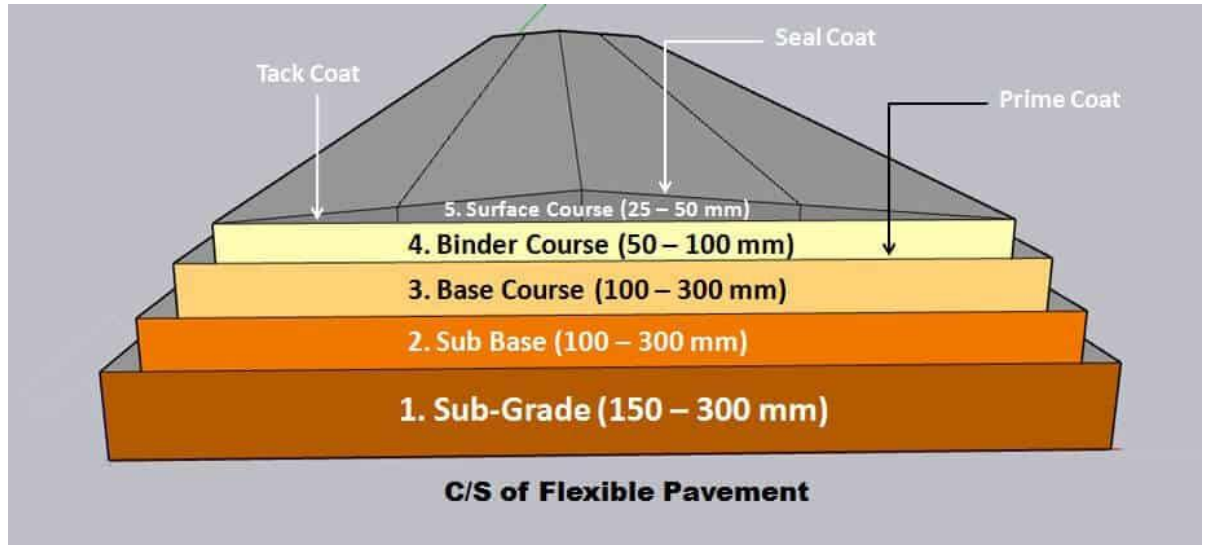

Figure 3. Flexible Pavement Layers

Next thing to be known for Flexible Pavement Road Preservation works is the different form of pavement distress or deterioration. A review of Flexible Pavement Deterioration had been established. Basically, the deterioration can be classified into five types, the pavement cracks, the pavement defects, the pavement deformation, the surface patches, and problems related to the soil \& terrain conditions. (Alaamri, Kattiparuthil \& Koya, 2007; Awaliyah, 2018; Awari, 2016; Bashir, 2006; Jayakumar \& Lee, 2015; Tamrakar, 2019; Yulianti \& Hasanah, 2018; Zaltoum, 2011). The review result is presented in the following Table 2.

Table 2. Flexible Pavement Deterioration

\begin{tabular}{|l|l|}
\hline Type & Deterioration \\
\hline Crack & $\begin{array}{l}\text { alligator \& fatigue cracking, block cracking, } \\
\text { longitudinal \& traverse cracking, edge cracking, } \\
\text { reflection cracking, slippage cracks. }\end{array}$ \\
\hline Pavement Defects & $\begin{array}{l}\text { crawl or shoving, rutting, convexities \& } \\
\text { concavity, corrugation, bleeding or flushing, } \\
\text { raveling \& weathering, polished agregate, sell. }\end{array}$ \\
\hline Pavement Deformation & depression, lane shoulder droped, potholes \\
\hline Surface Patches & patching, utility cut patching \\
\hline Soil \& Terrain Problem & landslides, seroius settlements \\
\hline
\end{tabular}

Several examples of Flexible Pavement Deterioration Types are presented in Figure 4 Figure 7 as follows. These illustrations cover mainly examples of road cracks, road potholes, road landslides, and difficult soil and terrain problems.

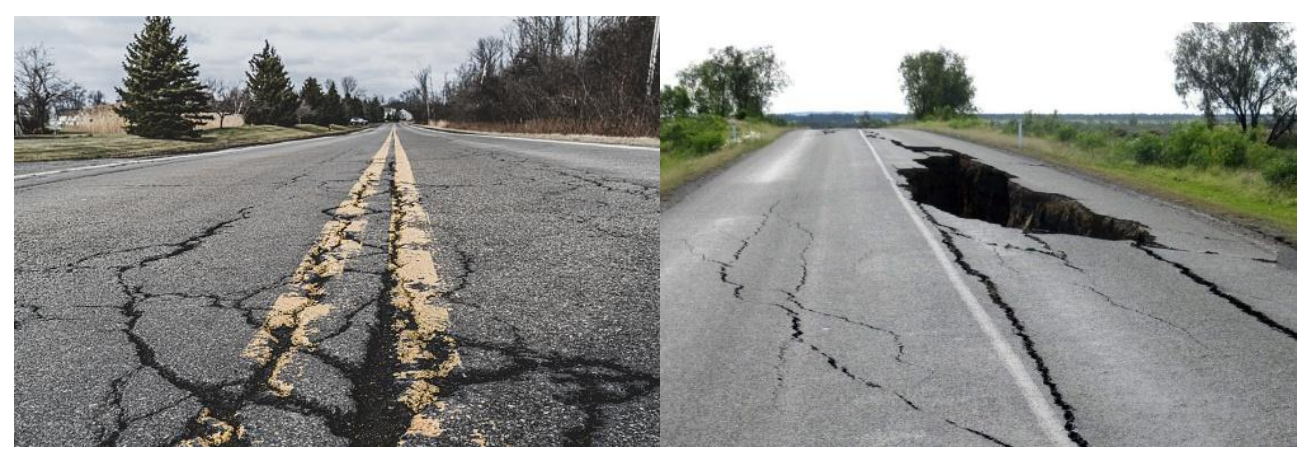

Figure 4. Road Cracks 


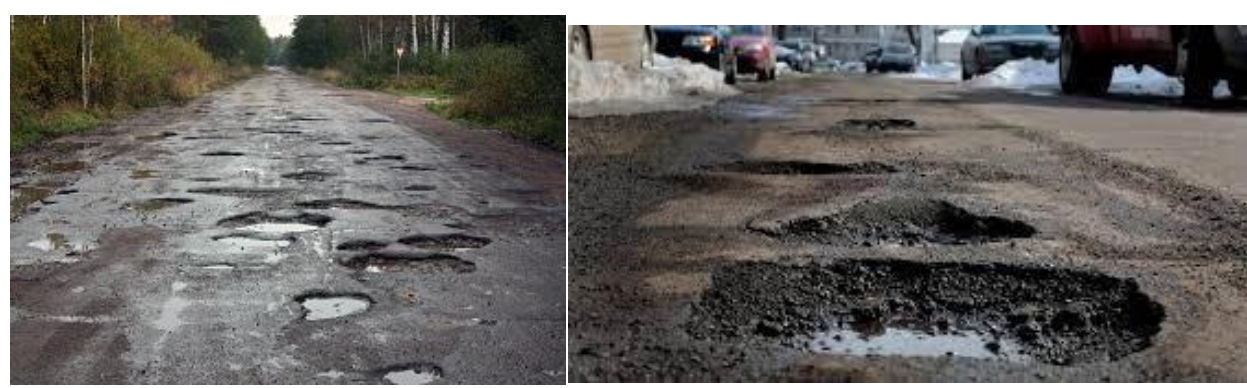

Figure 5. Road Potholes

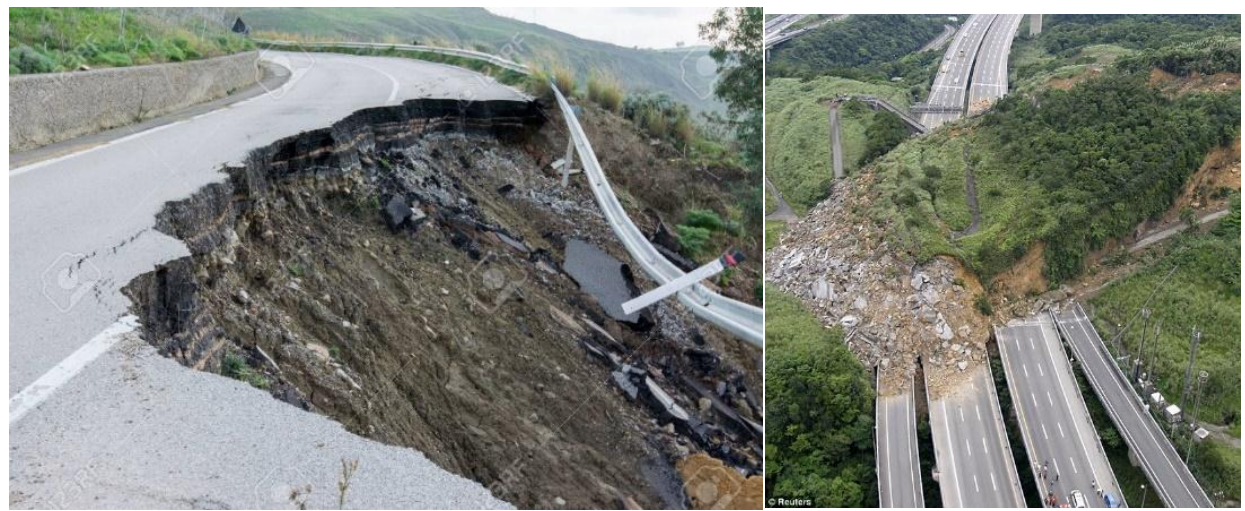

Figure 6. Road Landslides

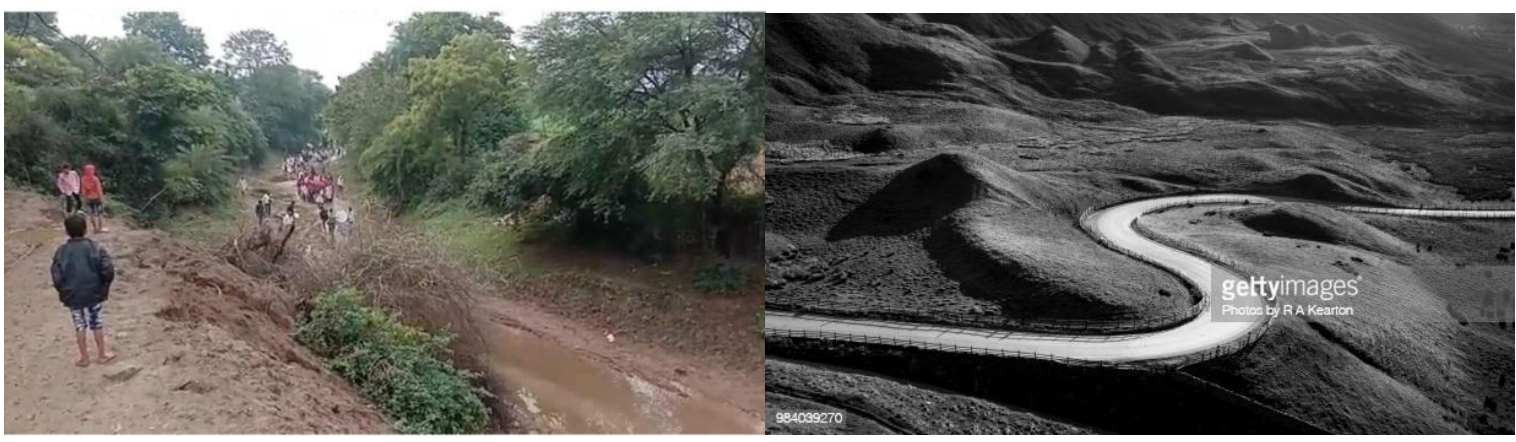

Figure 7. Road in Difficult Soil and Terrain Condition

\section{CONCLUSIONS}

Finally, the review research arrived to the several important notes concerning the road preservation works as follows.

- Road is built to perform a certain function. The function can be divided into primary and secondary function.

- Road segment must be divided into several components.

- Road Pavement components is the most important for the road primary function.

- Flexible Pavement components can be divided into surface layers, base layers, subgrade layers and general soil and terrain components.

- Very often, in certain areas, difficult soil and terrain condition is the main factors for the road preservation problem.

As road preservation knowledge, this research result is still very basic. For developing further basic knowledge development, this research should be developed to improve the understanding of the pavement deterioration, i.e. the types, the varieties, the mechanism of deterioration, the cause and the solution. 
Notes : This paper is part of Working Papers to develop the Knowledge and Science of Infrastructure Asset Management System. This particular paper is designated to deepen our knowledge especially on Road Preservation System.

\section{REFERENCES}

Alaamri, R.S.N., Kattiparuthi,R.A. \& Koya, A.M. (2007). "Evaluation of Flexible Pavement Failures - A Case Study on Izki Road". IJAEMS - International Journal of Advanced Engineering, Management and Scence, 3(7), July 2017, pp.: 741-749.

Awaliyah, Wildatun (2018). Analisis Teknik Preservasi Jalan Lintas Timur Dalam Kota Palembang, (Studi Kasus: Ruas Jalan Availability Payment, Jalan Soekarno-Hatta). Skripsi S1. Jurusan Teknik Sipil. Universitas Sriwijaya.

Awari, M.B. (2016). "Flexible Pavements Deterioration and Solutions". VSRD International Journal of Mechanical, Civil, Automobile and Production Engineering, 6(10), November 2016, pp.: 271-274.

Bashir, M. (2006). Effect of Thermal Cracking and Environmental Condition on Asphalt Pavement. Master Dissertation. Al-Meghreb University. Khoms.

Dewi, D.K., Soemitro, R.A.A., Suprayitno, H. \& Budianto, H. (2020). "Pemanfaatan BagianBagian Jalan Nasional, Studi Kasus di Ruas Jalan MERR Surabaya". JMAIF - Jurnal Manajemen Aset Infrastruktur \& Fasilitas, 4(3), Juli 2020.

Hoffman, C. (2008). Basic Structural Elements - Pavement Interactive. http://www.pavementinteractive.org/index.php?title=Base\#Surface_Course. Accesed: 28 December 2021.

ISO 55000. ISO 55000:2014 - Asset Management - Overview, Principle, Terminology.

Jayakumar, M. \& Lee, C.S. (2015). "Study on Flexible Pavement Failures in Soft Soil Tropical Regions". CUTSE 2015. IOP Conf. Series: Materials Science and Engineering 78 (2015) 012002.

Kiranasari, R.W., Soemitro, R.A.A., Suprayitno, H. \& Budianto, H. (2020). "Penentuan Faktor bagi Analisis Faktor Keberhasilan Proyek Preservasi Jalan Skema Long Segment". JMAIF - Jurnal Manajemen Aset Infrastruktur \& Fasilitas, 4(2), April 2020.

PerMen PUPR 34/16. Peraturan Menteri PUPR Nomor 34/PRT/2016 tentang Jalan.

PP 34/06. Peraturan Pemerintah Republik Indonesia Nomor 34 Tahun 2006 tentang Jalan.

PP 28/20. Peraturan Pemerintah Republik Indonesia Nomor 28 Tahun 2020 tentang Perubahan atas Peraturan Pemerintah Republik Indonesia Nomor 27 Tahun 2014 tentang Pengelolaan Barang Milik Negara/Daerah.

PP 27/14. Peraturan Pemerintah Republik Indonesia Nomor 27 Tahun 2014 tentang Pengelolaan Barang Milik Negara/Daerah.

Ridwan, N. \& Putranto. L.S. (2020). "Indikator Kinerja Jalan Long Segment di Banten dengan Analisis Analytical Hierarchy Process". Jurnal Muara Sains, Teknologi, Kedokteran dan Ilmu Kesehatan 4(1), April 2020, hal. 131-144.

Sinaga, H.P. (2011). Manajemen Preservasi Jalan untuk Pengelolaan Jaringan Jalan Wilayah. Pusat Penelitian dan Pengembangan Jalan dan Jembatan. Bandung.

Suprayitno, H. (2014). Metoda Penilaian Kualitas Jarinagn Jalan Utama di Wilayah Kabupaten. Disertasi. RC 09-3399. Jurusan Teknik Sipil, Institut Teknologi Sepuluh Nopember. Surabaya.

Suprayitno, H. (2021). "Pengenalan Lingkup Manajemen Aset". I4 Lecture Series in Geography Transportation Built Engineering \& Infrastructure, 10 April 2021.

Suprayitno, H. \& Soemitro, R.A.A. (2018). "Preliminary Reflexion on Basic Principle of Infrastructure Asset Management". Jurnal Manajemen Aset Infrastruktur \& Fasilitas JMAIF 2(1), Maret 2018, hal.: 1-10. 
Suprayitno, H. \& Soemitro, R.A.A. (2019). "Reflection of Basic View of Public Infastructure for Infrastructure Asset Management in Indonesia". JMAIF - Jurnal Manajemen Aset Infrastruktur \& Fasilitas, 3(Suplemen 1), Juni 2019.

Suprayitno, H. \& Soemitro, R.A.A. (2021). "Knowledge Needed and Management Notion for Infrastructure Asset Management". Workshop S2 Super Spesialis - Preservasi Jalan 2021 \& SeMAIF - Seminar Nasional Manajemen Aset Infrastruktur \& Fasilitas \#2 2021.

Tamrakar, N.K. (2019). "Overview on Causes of Flexible Pavement Distress". Bulletin of Nepal Geological Society, 2019, Vol. 36.

UU 1/04. Undang Undang Republik Indonesia Nomor 1 Tahun 2004 tentang Perbendaharaan Negara.

UU 38/04. Undang-Undang Republik Indonesia Nomor 38 Tahun 2004 tentang Jalan.

Yulianti, R. \& Hasanah, B. (2018). "Implementasi Program Pemeliharaan Jalan di Dinas Pekerjaan Umum dan Penataan Ruang (PUPR) di Kabupaten Pandeglang”. Jurnal SAWALA 6(2), Oktober 2018, hal. 111-125.

Zaltoum, A.M.A. (2011). Evaluation Pavement Distress Using Pavement Condition Index. Master Thesis. Post Graduate. Universitas Diponegoro. Semarang. 